\title{
Yorkshire and The Humber
}

\section{Map 6.3 Population density: by local or unitary authority, 2008}
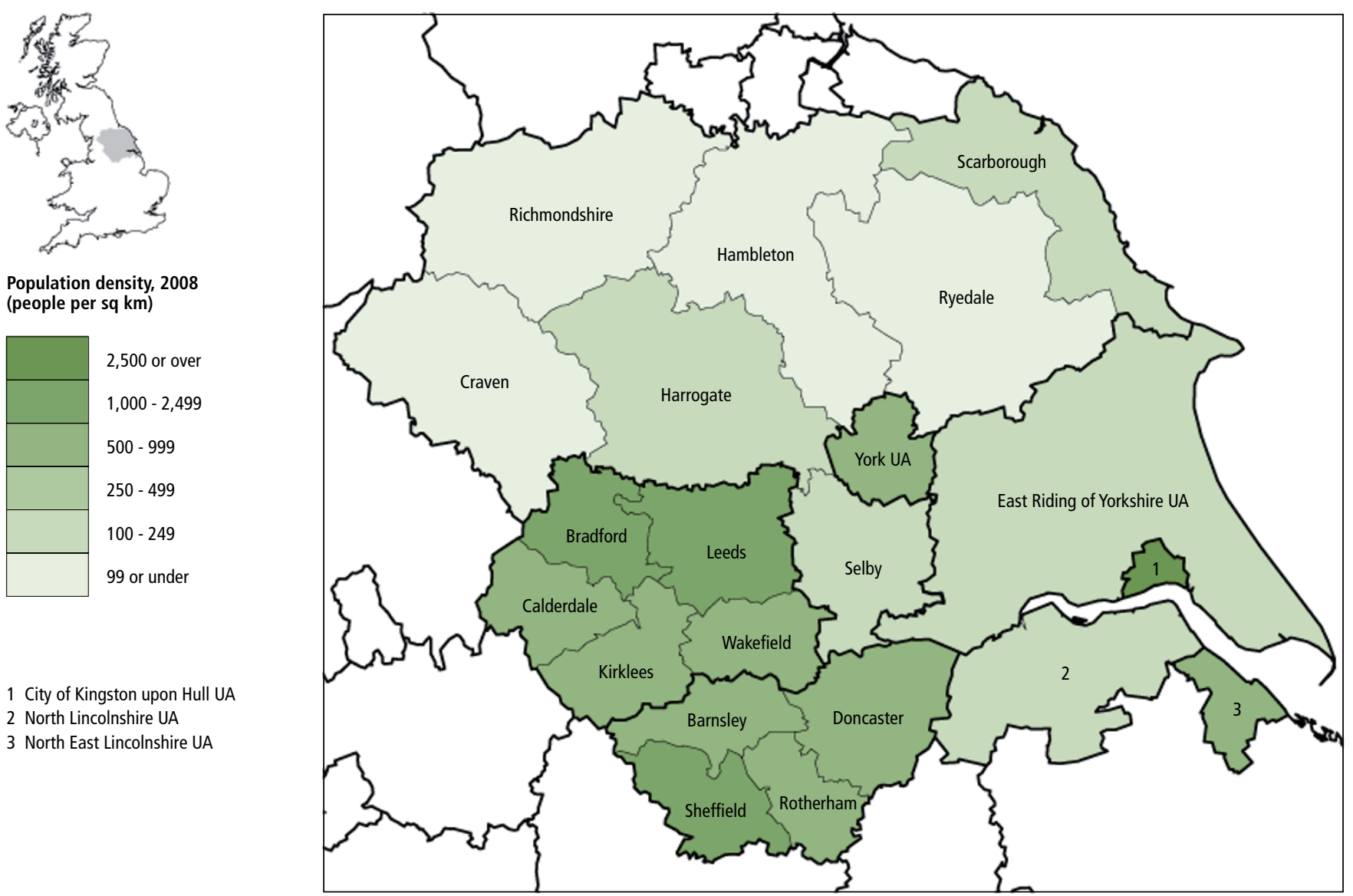

1 City of Kingston upon Hull UA

2 North Lincolnshire UA

3 North East Lincolnshire UA

(people per sq $\mathrm{km}$ )

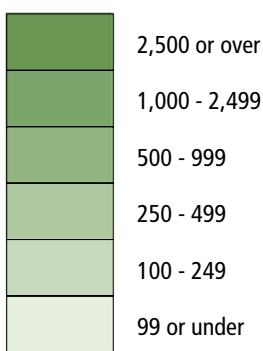

- Yorkshire and The Humber had a population of 5.2 million in mid-2008, an increase of 3.7 per cent since 2003. This compares with an overall increase of 3.1 per cent for the UK over the same period (Online table 1.2).

- People over state pension age (65 and over for men and 60 and over for women) in Yorkshire and The Humber in 2008 made up 19.1 per cent of the population, compared with 18.6 per cent for the under-16s. This compares with averages for the UK of 19.2 per cent and 18.8 per cent respectively (Online table 10.3).

- In Yorkshire and The Humber, men aged 65 in 2006-08 could expect to live another 17.2 years and women 19.8 years. This compares with 17.5 and 20.2 years in the UK as a whole (Online table 6.8).

- In Yorkshire and The Humber, 44.4 per cent of pupils achieved five or more grades $A^{*}-C$ at GCSE level or equivalent including English and mathematics in 2007/08, compared with 47.7 per cent for the UK as a whole (Online table 4.8).
- The unemployment rate in Yorkshire and The Humber stood at 9.1 per cent in the fourth quarter of 2009, higher than the UK rate of 7.8 per cent (Online table 1.1).

- The proportion of children living in workless households in the second quarter of 2009 was higher in Yorkshire and The Humber (18 per cent) than the England average (17 per cent) (Online table 8.6).

- In April 2009, the median gross weekly earnings for full-time employees on adult rates who were resident in Yorkshire and The Humber was $\mathrm{f452}$, lower than the UK median of $£ 489$ (Online table 9.19).

- Labour productivity (gross value added per hour worked) in Yorkshire and The Humber in 2008 was 10.8 per cent below the UK average (Online table 3.2).

- Local authorities in Yorkshire and The Humber recycled 31 per cent of household waste in 2007/08 compared with an England average of 35 per cent (Online table 5.11). 